\title{
Meganarratives Of Supermodernism: The Spectre Of The Public Sphere
}

\author{
MARK KiNGWELL
}

\section{Modern, Postmodern, Supermodern}

It is a truism, but a worthwhile one, to note that the concept of postmodernism was adumbrated in architecture before appearing elsewhere, a language and a style before it was a condition or a form of knowledge suitable to, or demanding of, report (see Jencks, Post-Modern; Lyotard). To be sure, as Fredric Jameson acknowledges in his preface to the English translation of Lyotard's The Postmodern Condition, the specifically architectural use of the adjective is distinct, indeed narrower, in referring mostly (and often indeterminately) to a cluster or trend of building designs that sought release from the rigid sleekness of normative architectural modernism by mixing and quoting various styles and through liberal use of materials. Frank Lloyd Wright's organicism, for example, is transitional in a wide historical sweep that moves from the utopian aspirations of Le Corbusier and Mies van der Rohe to the contextualism and allusiveness characteristic of late-century building.

Such narratives are of course themselves worthy of suspicion if not incredulity; they are, like the detective's solution, imposed post facto as a form of libidinal release under the aegis of telling a coherent story, which is to say making sense. ${ }^{1}$ And yet, despite differences of specificity in usage, the mixture of bricolagiste style with a 
perceived collapse of undiluted "rational" aspiration makes postmodern architecture not unlike postmodern thought more generally; and, as with the often remarked but never resolved slippage between modernism (in architecture, in poetry) and modernity (in politics, in society), style is a fitting and dynamic relative, perhaps codeterminant, of the historical condition. Jameson rightly argues that postmodern architecture was, at least in part, an intellectual reaction against the perceived failure of utopian social-revolutionary agendas associated with Le Corbusier and Mies (and, less accurately, Wright). "[T]he new buildings of Le Corbusier and Wright did not finally change the world, nor even modify the junk space of late capitalism," he says, "while the Mallarmean 'zero degree' of Mies's towers quite unexpectedly began to generate a whole overpopulation of the shoddiest glass boxes in all the major urban centers of the world" (Jameson, preface to Lyotard xvii).

This is what we may label the standard view, with an aggressive and idealistic modernism burning itself out in an excess of post-war construction, such that critics soon saw that "its Utopian ambitions were unrealizable and its formal innovations exhausted" (Jameson, preface to Lyotard xvii). So the story goes. And according to this dominant narrative - a narrative which we shall employ, per Žižek, as at once contingent and necessary - architecture now progressed, or anyway moved on, from this adolescent utopian ambition and onto a different stylistic crisis, with the leading figures now united not on anything like a style, or even a theory, but in what might be called an attitude, in many cases meeting the conditions of displacement and disintegration characteristic of globalized development with a large-scale and stylistic form of building Hans Ibelings 
and Marc Augé, among others, have labelled "supermodernism," citing among others the work of Jean Nouvel and Dominique Perrault (e.g., see Ibelings 54 ff). In addition, these constructions are often found as part of the centreless conurbation Charles Jencks dubbed the "heteropolis," the City-of-Tomorrow masses in Berlin's Potsdamer Platz and Shanghai's Pudong New City, often exhibiting what I have elsewhere called "monumental-conceptual architecture" - signature buildings, many of them gestural, on a vast scale ("Architecture"). This is, we might say, architecture of meganarrative, not metanarrative.

The Berlin-based architect Daniel Libeskind was recently in the public eye for his World Trade Center reconstruction project and subsequent ouster by David Childs of Skidmore, Owings \& Merrill (the longstanding skyscraper master-firm from Chicago) who gained control of that much-disputed project. Libeskind is also the muse behind a less spectacular project, the three-year, \$150-million renovation - or "renaissance" - of the Royal Ontario Museum (ROM) in Toronto. In both designs Libeskind has shown himself a master of high-profile success in the current architectural market. The ROM project especially, a striking crystalline outline, is a good example of the sort of mutation a recent vogue for distinctive, high-profile architecture, often in museums, has created though it was not included in a 2003 Berlin retrospective exhibition of Libeskind's designs, the crystal design represented instead by the closely similar Victoria and Albert Museum renovation, since abandoned. These architectural megaprojects, including Frank Gehry's Bilbao Guggenheim, Eisenman's Wexner Center for the Arts at Ohio State University and Galician Cultural Center in Santiago de Compostela, and Libeskind's Jewish Museum in Berlin, exert an influence disproportionate to their number, becoming 
the focus of most recent non-academic (and much academic) debate about architecture. With the possible exception of airports, a more obvious supermodern site, museums emerged as the central Baustellung, and the dominant form, of the new century. To be sure, far more building is in fact being done in more banal forms, notably the many dozens of high-rise residential and office towers rising everywhere from London's Canary Wharf to Shanghai's far-flung suburbs to Toronto's waterfront; but this great volume of undistinguished square-footage, surely more indicative in its mediocre way of the dreary downside of supermodernism, does not acquire the status of a signature building literally does not signify - and so fails to be noticed.

This cannot be surprising. Their position astride major public spaces makes the megaprojects highly visible, usually through public money and major municipal cooperation. Like all urban architecture, they belong to everyone, including future generations. In many cases, they are driven by form rather than content. The Bilbao Guggenheim, for example, was not built to house or display an existing collection - there was none - but as a \$100-million, 256,000 square foot end in itself. The Galician Centre, with a projected cost of \$125-million and 810,000 square feet, also has no existing collection, selling itself instead on the 173 acre mountaintop site and Eisenman's thrusting stone walls that one commentator describes as looking "as if they were pushed right up through the earth" (Merkel 67). The irony in play is not precisely postmodern but is nevertheless striking. The public warehouse of artefacts, itself a modern invention dedicated to democratized cultural sophistication, offered a narrative of general diffusion and edification as private collections became public in well-marked public places. Now it 
is self-displaced by the museum as artefact, the so-called destination building visited more for its exterior than anything within; functionally, such museums might as well remain empty. Arthur Danto, prompted by the aggressive anti-monumental facade of the Museum of Modern Art on West 53rd Street in Manhattan, half foresaw this development. MoMA (itself a self-conscious familiarity) reduced a previously grandiose institution, the art museum, to just another midtown storefront, a signal resistance. Danto's notional "museum of museums" would trace such lines of change from deliberately intimidating Beaux-Arts neo-classicism, with long staircases and columns consonant with edifying Great Masters, to clean-limbed modernist scepticism, suitable to Pollock or Klee (Danto, Brillo Box 210-12). What Danto did not, and could not, see was that the museums themselves would usurp the bulk of attention and dispense with the works entirely, outstripping them in a media-saturated aura economy.

All these projects, and others of even more recent vintage - Diller + Scofidio's Museum of Contemporary Art in Boston and, still more, their Blur Building on Lake Neuchatel at Yverdon-les-Bains, Switzerland, a "structure" that exists only as a manmade fog mass suspended above a ramped bridge - share a penchant for the monumentalconceptual. Moreover, many of the now-familiar architectural stars hard at work securing and realizing such large-scale public commissions were first celebrated in a 1988 show at the Museum of Modern Art in New York, assembled by Philip Johnson and guided by Eisenman, which marked a development of modernism from within its own radical wings. Gehry, Libeskind, and Eisenman were joined in the show by Zaha Hadid, Rem Koolhaas, Bernard Tschumi and Wolf Prix of Coop Himmelblau. (In recent years architecture's most prestigious prize, the Pritzker, has gone to Koolhaas, in 2002, and 
Hadid, in 2003.) The personalities of such figures are indispensable to the cultural contradictions typical of supermodernism, its uneasy but necessary celebration of a great man stereotype, a visionary hero, is often communicated synecdochically by their preliminary sketches, which become tropes of genius sold on t-shirts, baseball caps and the like in the museum gift shop - the frozen gesture of genius, swiftly commodified.

This superstructure of aesthetic romanticism, updated via technology, rests atop a diversified but invisible base of labour and capital, usually an undisclosed mixture of public and private. Donors are lauded by their desire to consort with genius, to ally themselves with a vision. Thus the institutional pressure from all sides to maintain and extend the great-man myth, the meganarrative, is considerable. A second-order contradiction, indeed pathology, arises when a perceived outsider who attempts criticism of the works is often personally attacked in return, or disallowed from the debate a clear sign of subcutaneous unease about the "genius" of the designs and the hermetic circle around them. Sometimes these counterstrikes come in a form of accusations using the very categories the critic challenged: the benefits of an economy of celebrity, (lack of) visionary status, the importance of preliminary sketches, etc. Such charges are, to say the least, confused.

\section{Style}

Monumental-conceptual architecture, as I use the term, is not to be confused with simple theoretical architecture. Waves of theory-driven architecture are hardly new, with ideas borrowed liberally from fashionable philosophical works emanating mainly from 
Paris, Bologna and Berlin - Eisenman's use of Chomsky, Derrida and Vattimo; Tschumi's debt to Debord and the Situationists; Diller + Scofidio's Lacanian probes; everyone's use of Heidegger and Benjamin (see Leach and Denari). From the admittedly judgmental perspective of professional philosophy, such "theory" architects and, especially, their lesser acolytes, often appear to be little more than intellectual magpies, distracted by anything shiny and new. In this they might be said merely to follow, perhaps to refine, a tendency already deeply inscribed in the collective practice of architect talk, what the critic Nathan Silver memorably describes as a tendency "a bit like advertising, with ideals and cultural pretensions added ... as if dug out from a kitchen midden of contemporary jargon, ideological polemic, historical reference, and some overcolored scenic description" (325).

Architect talk, says Silver, "is not an orderly string of words but a field ... a landscape" in which any available marker, or sign, may be seconded to service (326). Its primary function is not thought itself but, rather, influence on the outcome of a complicated decision that will create something providing, at its best, the occasion for thought. Thus the relentless shifting of reference points, a restless sense of novelty, as theorists and indeed individual concept words, fall in and out of fashion. ${ }^{2}$ In this sense, architect talk, and so a fortiori architect theory, is always already unmoored from the dock of sense, more a phatic performance, an exchange of blank tokens, than the communication and debate of ideas.

The theory-driven architects of the late postmodern exemplify this tendency in a manner, and, to a degree, Silver himself, writing in the late 1970s, could not have fully anticipated the vogueish intellectual trends, or rather the trendy versions of intellectual 
positions, still to come. But at least the debts incurred by these architects were, in most cases, openly stated, and sometimes added to the complexity of the thoughts the buildings occasioned - surely as much as can reasonably be asked. If a Deconstructionist building or Deleuzian blob-and-fold structure should prove to be less interesting in reality than in theory, well, so what? One could always simply note the theory, judge the building on its merits, and move on. Nor was the theoretical cross-pollination all for show. Many of the most successful buildings of the past twenty years, especially Hadid's and (some of) Gehry's - and here one could add lesser-known Canadian names such as Douglas Cardinal and KPMB of Toronto - are masterpieces of situation, transforming sites with mixed materials and arresting spaces in a manner unavailable to either modernist or postmodernist styles. And yet, even here a certain sameness emerges, especially in hotel and airport designs - paradigmatic supermodern locations. The ubiquity of "warm" millwork, stained wood slats, rounded armchairs, and brushed-steel handrails reduces them to banal signifiers of "luxury" or "prestige," those Asian-minimalist inflections that project the glossy look of upmarket retail locations and frequent-flyer hotel lobbies alike, unvarying from Zürich to London to Sydney or Hong Kong.

The newest large-scale works pose a somewhat different problem, one characteristic of the postmodern-supermodern shift. Though Johnson's show grouped Gehry, Koolhaas, Libeskind, and the rest under the banner of deconstructionist literary theory, in fact the group is united only in their facility with ideas and subsequent success, especially in highly contested museum commissions. With open theory-debts now somewhat out of fashion, architects of the first order have taken to selling their game in 
terms of concepts rather than theories - a sketch or simulacrum of theory, a theory of theory, where ideas are often unmoored and scattered (also, to be fair, sometimes brilliant and bold). The theory sketch and the literal sketch are related insofar as the latter becomes a signifier (albeit a false one) of possession or mastery with respect to the former, and hence its susceptibility to the very consumeristic reproduction which renders it null. Theory/concept is a fine distinction, but I suggest that its essence is a matter of responsibility. Theory, whatever else it does, makes demands of a sort that still themselves signify, despite any anti-modern efforts to the contrary: demands, that is, of coherence, of consistency in application, of defensibility. Concepts, as I shall use the term, and the monumental-conceptual architecture they allow, are free-floating and undemanding, such that the mere play of ideas, the juggling of concepts, is seen as a sufficient justification, an end in itself. Postmodern architecture was not conceptual in this sense; it was, approve the adjective or not, theoretical.

The question then becomes: are the monumental-conceptual works living up to the responsibility of public money and public attention, or are they large-scale con games feeding the self-indulgence of a new breed of installation artists, the architect as seer? To answer that question we must not only examine current architectural practice but appreciate marked slippages in the notion of public space. Though much of the rhetoric of late-modern debate was and is condemnatory regarding current urban experience (see, for example: Sennett; Frampton; Casey, Back into Place), it is far from obvious that calls for returns to public space, or enlarged versions thereof, are valid, or anyway, are free of lingering vestiges of a utopianism we might regard as bogus or unsupported. Nor, for that matter, is it immediately clear that a more implaced or situated architecture is the answer 
to alleged losses in democratic accountability or individual connection to the built environment. Here, indeed, modernist narratives of emancipation and participation linger far past their dismantling in other quarters. Nevertheless, we must take seriously the calls for a vibrant public sphere and subject them to the close attention that neither architectural monumentalism, often self-congratulatory or self-indulgent, nor everyday denunciations, often short-sighted or driven by narrow grievance, allow.

The issue is considerably complicated by the dynamic between style and substance, or rather, by the fact that, here, style is a substantive issue. While the very idea of style is regarded with dismay or even disdain by many architects anxious not to have theirs cramped by expectations arising from previous buildings (see Rybczynski ch. 1), it is nevertheless employed by them to divide the field of building, past and present, as minutely (if not as precisely) as the language of construction orders the parts and tasks of building itself. In the latter case the imperatives are straightforward, indeed almost Wittgensteinian: we move from block, slab, pillar, beam and "I want you to bring me a slab" (Wittgenstein 3) to finer grades of meaning-use realized by finials, cladding, aedicules, dentils, annulets, modillions, and mutules. Style-designators can be as narrow but they are rarely as uncontroversial - or as useful. Charles Jencks, himself responsible for more than a few style-signs becoming widespread, among them "postmodern" itself, both parodies and celebrates the semiotics of architecture through fanciful gestures of naming in Daydream Houses of Los Angeles: "Spreadwing Cadillac," "Ronchamp Skijump with Mushroom Overtones," "Topiary Fascist." This might be considered the bright side of the very same "junk lingo" condemned by Silver, with its "nouning" of verbs (a 
"merge," a "surround"), fashionable logico-philosophical inflections, and agglutinative neologisms, often in German. These are, to use a building term already appropriated by biology among other discourses, spandrels: features of an edifice that serve no obvious purpose.

There can be no simple diagram for how verbal language meets visual language here (or indeed elsewhere); and philosophical discourse is hardly free from the very same forms of necromantic obfuscation found in architectural discourse. There can, moreover, be no clear line between a necessary piece of technical language and a bit of jargon employed to elevate the speaker and intimidate the listener. The real issue here must always be how, or how well, architecture serves the common good - a central concern at least since Vitruvius attempted to understand the meaning of architecture, and thus created a language of architecture. ${ }^{3}$ I therefore pose two cardinal questions for any practical language or sign-system oriented to the politics of the built environment: 1 . Does it make thought more or less likely? And 2. Does it exclude for the sake of exclusion? These questions, and these questions alone, can help us understand a public sphere that, though everywhere being materially constructed, remains spectral.

\section{Cities as Places}

In a common irony, the discussion of cities has over the last few decades reached a theoretical impasse at just the moment we most need liberating thought about the circumstances governing the bulk of human life. By the eighteenth century, theories of the city had developed the now-common circulatory model, the stone version of flow and health otherwise realized in flesh by William Harvey's maps of the blood-paved body. 
Adam Smith was among the first to view people, ideas, commodities and wealth as elements that flow and exchange, the physical conurbation as a material host to notional but powerful markets. Streets were seen as arteries, a usage still to be heard, and people or vehicles conduced without cease from place to place, held up by congestion or rubbish clogging the line. Hygiene was realized by scouring the conduits and, in a later development, first speculating then succumbing to the insatiable logic of faster flow. Then, more lately still, the current began to slow and, sometimes, cease: gridlock.

Likewise, unfortunately, in the stream of ideas about the problem, since widening freeways destroyed fabric without easing traffic, and exurban sprawl created faceless housing tracts where notions of place and dwelling were difficult, if not impossible, to achieve. Or, in far worse and more populous conditions, the largest cities of the latemodern world, most of them outside the so-called developed world, became vast warrened slums of cheap concrete high-rises and makeshift shanties.

Now complaints about the problems of the city are uniform, to the point where it seems only logical to declare cities over and start again. "After a century's criticism of the large city," Jürgen Habermas wrote,

after innumerable, repeated, and disillusioned attempts to keep a balance in the cities, to save the inner cities, to divide urban space into residential areas and commercial quarters, industrial facilities and garden suburbs; private and public zones; to build habitable satellite towns; to rehabilitate slum areas; to regulate traffic more sensibly, etc. - the question that is brought to mind is whether the actual notion of the city has not itself been superseded ("Modern" 326).

The average hyperindustrial modern city is a cluster - or more likely, sprawl - of diverse and unconnected interests, linked by phone lines and shared sewage but otherwise exclusive and mute. The city centre is a site of mixed functions layered over one another, 
no longer, as in early modern cities, differentiated by a formal architectural vocabulary but all inhabiting the same multipurpose function-boxes and distinguishing themselves by logos or brand identities. Which identities, however spectral and merely graphic, sometimes outpace or supersede the original function, becoming, in a now familiar postmodern twist, the focus of our attention.

Our relationship to these cities is likewise increasingly spectral. We arrive and leave via an airport, miles from the city centre and itself a node of passage hardly distinguishable one from another, despite attempts at domestication or aestheticization. The airport has itself become, in fact, the twenty-first century city: not merely an extension but the most vivid expression of the consumption/movement imperatives of current urbanism. No one needs to be told that cities are no longer centres of production or manufacture but of shopping, food, and entertainment. The airport is not merely a gateway but a placeless apotheosis of this truism, a nexus in which we always spend more time than we would wish, our aroused fears and security consciousness dulled by familiar shops - Tie Rack, Sharper Image, Gap - themselves designed to palliate our unease. Anchored only by portable laptops and email connections, we are at once there and not there, travelling and immobile, suspended not over the open road of romance but the interchangeable gates and carousels of life, waiting, always waiting, for a row to be called, a bag to appear: the tiny miracles, alone apparently magical, of postmodern existence.

Or perhaps we still drive into the city, our fossil-fuelled sports utility vehicles, ever expanding in size, sizzling along on concrete expressways whose very signage signals the uniformity of our automotive urban experience, unchanged from Vancouver to 
Brisbane, from Miami to Hong Kong. Rare, except for backpacking Euro-travellers or weary commuters, is the Industrial Age experience of entering the city from within, via the vaulted neo-classical expanses of the downtown railway station. Impossible, to be sure, is the daunting threshold experience of being allowed passage through the premodern city gate, exchanging wilderness for civilization and plenty - that drama of judgement and approval is now shrunken to the velvet-rope boundaries of nightclubs and bars, the inner glow of noise and revelry offering invidious contrast to the dark lonely street.

More than this, the forms of our interaction have, in another familiar postmodern development, lost concreteness. It is not only that, as Habermas says, "the urban habitat is increasingly being mediated by systemic relations, which cannot be given concrete form." It is also that those systemic relations themselves are impersonal and virtual. Cities are nodes of population but they are no longer the nodes of power, which rather exist in a placeless universe of networked exchange. The central tension of postmodern life is not the lack of a governing narrative of meaning, though that afflicts too many of us and empowers the violent narratives of meaning told by others. This familiar collapse of narrative coherence is merely a symptom of a larger malaise, an unease rooted in the conflict between placelessness as the logical outcome of the modern experiment, where time and space are first abstractly created, then systematically annihilated by the pursuit of speed and the cult of efficiency, and a persistent human desire for location. The central victim here is an awareness of the real facticity of life, what Edward Casey calls, in Getting Back into Place, "embodied implacement." 
We are incapable of imagining experience without our embodied selves; experience is always of embodied self. And embodied self is always somewhere in particular, in a place. And yet, as Casey argues, place is the most overlooked - indeed, the most comprehensively denied - category of philosophical analysis. We are busy destroying our feeling for place even as it remains the one constant, the fundamental precondition of all human experience. The resulting spread of atopia, or placelessness, is the real postmodern condition - an affliction we share with certain modern and indeed premodern peoples, but with the difference that we now actively pursue our own displacement in the form of a cure worse than the disease, the ultimate iatrogenic illness.

At the same time, and even if we accept that a project of renewed implacement is appropriate (or even available) to the public sphere, we must be careful not to fall into a simple exchange of space-dominance for place-dominance. There is such a thing as an experience (not just employment) of abstract space - as when, for instance, I "find myself" on a map or grid, and experience the delicious vertigo, itself thoroughly a product of modernity, of whipsawing between my sense of myself as a body and my sense of myself as a point of location; this is the pleasurable, almost erotic feeling of bird's-eye surveillance and dominance afforded us by the very abstraction of threedimensional space. This is almost, we might say, an out-of-body experience, whereby I float above places, and myself in them, to view the world from two perspectives of place and space at once. The map, per convention, offers me a location and hence an orientation: "You are here" below an arrow and dot. Such maps, if oriented so that the dot is anywhere other than the bottom, risk orientation failure: they do not take into account 
the complex dialectic between my embodiment in place and its relation precisely to my experience of abstract location, the way up in maps translates to in front of in place.

In an old New Yorker cartoon, the map of the Philosophy Department carries a different label below the dot and arrow: "Why are you here?" An even more pertinent question for our purposes, one which works by enfolding these others, mundane and satirical, is "How can you be here?" What is it to be in a place within a world of space, both embodied and disembodied, both inside and outside? Spatial influence is vast, and cries out for counter-valence; but we make a grievous error if, in challenging Cartesian conventions, we simply replace one unbalanced account with another.

\section{Legacies of Abstraction}

For some years, philosophers interested in epistemology, justice theory and the idea of public space have struggled with three linked frustrations generated by three kinds of disciplinary blindness - no uncommon fault in certain forms of intellectual effort. They are legacies of, respectively, the theory of consciousness; modern architectural theory; and liberal political theory. These frustrations explain the motivation and intent behind any political critique of architecture, and so it is worth dwelling on them now, mindful always that there is a degree of caricature operating in any generalization of the following type (see Kingwell, World ch. 4).

The errors to be found in these views resemble, though fall short of identity with, the kind of dilemmas or category mistakes seized on by some philosophers of language. That is, they are not errors that can be solved with more effort of the same kind that 
generated them, and we look in vain if we merely look again. Such errors are, in other words, species of category mistake that can be cleared up, if at all, not by further investigation, still less by adjudication among options or rival versions, but rather by conceptual shifting alone. To use a metaphor first deployed with effect by Gilbert Ryle, the error here is to employ the wrong harness for the particular animal we are trying to drive (5 et passim.). Admirable for the horse, perhaps, but not for the camel; and freer use of the crop, a tighter grip on the reins, or imprecations of mounting urgency are all useless or worse. We must dismount and rethink.

First, then, the theories of consciousness that have come to dominate the field, especially the reductionist and sometimes eliminativist accounts inspired by neuroscience, seem at best unhelpful and at worst actively distorted. Even when a conscious entity survives the fine-edged attention of our tribe's sharpest minds - as, for instance, when Daniel Dennett gets through explaining consciousness or John McDowell illuminates the link of mind to world - there is a lingering sense that the entities so explained or illuminated do not exist anywhere in particular, indeed that the investigation is predicated on abstraction and isolation of the entities 'mind' and 'world'. That is, even a multiple-drafts or centre-of-narrative-gravity consciousness, a consciousness to whom, as it were, I can relate (as opposed to the user-illusion "consciousness" explained, then erased, by a less forgiving theory, "whom" I can only regard with bafflement, especially if "it" is supposed to bear implications for, or indeed be, me), does not seem to possess the sort of concreteness, in particular of embodiment, I associate with my own experience of consciousness - of being here, in my room or out on the street, drinking a coffee or reading the paper. 
To approach consciousness as a property or condition to be explained - at least, explained in the outside-in way typical of modern scientific thinking - is to make an error that can only generate further errors. The consciousness this approach uncovers is everywhere and nowhere, a generic neutral non-particular property (or perhaps entity) which bears no relation to the embodied consciousness which is alone a matter of our experience: from the inside out, you might say, but using such language only as a handy first stab at metaphor, since the very notions of inside and outside are the questions consciousness as we really know it perpetually engages, and undermines. The abstracted outside-in consciousness is not real, but instead a philosophical fiction - as much a philosophical fiction, despite many argumentative improvements and fine-grained problem solving over three and a half centuries, as the Cartesian disembodied consciousness whose discovery (which is to say, invention) started the disastrous confusion. Such a consciousness does not sit or stand or dance a meaningless jig; it does not walk or eat or void itself; it does not live in a house or drive a Jaguar or smoke a cigar in the garden. It has no existence of its own, but is instead sustained alone, and solely, by the philosophical attentions of its creators, those mad scientists of the Gedankenexperiement. We could not ask it over for dinner, offer it the best walking route by which to come, offer it a gin and tonic on arrival. This consciousness is not from anywhere and does not long to return there. It can't tell you about its home town's parks, the fragrance of blooming eucalyptus on steep bay-side streets, or sweet fresh-cut grass mixed with blacktop tar in the schoolyard where only summer sunsets have power of death over an endless baseball game. 
Second, then, a parallel frustration. In the theoretical discussions of architecture, often enough in the practice of architecture itself, there are, to put it bluntly, no people. Often despite genuine effort on the part of some, the drawings and models of the built environment's creators act to reduce the streets surrounding a building to blank white avenues, denuded, pedestrian-free, neutron-bombed. Too often, despite Rossi- and Jacobs-influenced rhetoric of new urbanism, buildings are conceived and planned not as felt responses to need but as ordered patterns of intersecting planes and masses. Stylized plastic couples, a dog-walking hausfrau and a lone briefcase-toting businessman are glued down to show scale, but there is no sense of the teeming mass of people who might rush toward those doors every morning, jam together in those too-narrow corridors at break time, or, perhaps worst of all, simply abandon that hopeful courtyard for the dead space it is. The logical extension (or apotheosis) of this people-free universe is the large scale model of a town or city, as for instance in the Shanghai Urban Planning Center, rendered in white plaster or painted wood, abstracted and clean, which marches away in orderly rows that give no hint of the tangled intersections, laundry-draped wires, ubiquitous smog and, above all, roiling odour and noise of a real city; no whisper of the dopplering sirens, angry horns, swishing tires and gunning engines, the rising buzz of conversation, garbage stink and wafting fuel fumes, sticky roasted nuts and damp hot dogs.

For every architect who perpetuates this exterminator's approach to the inhabitants, viewing humans as vermin unfortunately given access to the pristine edifice of imagination - "Do not change them," Peter Eisenman said, when told his sly staircases were causing falls and injuries, "they will never take stairs for granted again" - for every 
one of these, there are likely hundreds of well-intentioned architects who try, with the best will in the world, not to take people for granted. And there are architects sensitive to these issues working in an Arendtian spirit (e.g., Baird). Yet these efforts too often fail, demonstrating that this issue exceeds any question of intention. It is, rather, a function of the unlived, and unliveable, abstractions inherent in the necessary (seen as necessary) move from two dimensions to three, the insuperable conditions of building on the basis of drawing: a legacy, let it be added, of the very same Cartesian revolution that skewed the vision of philosophers of mind, only now that part of the revolution which lays down, not the isolated disembodied mind, but the foursquare plan of abstracted planar space, the grid of rationality now lying over everything from the island of Manhattan to the background on which these words appear before you. The Cartesian exterior, which models sites rather than real places, is a mirror image of the Cartesian interior, which models 'thoughts' rather than lived experience.

The political dimensions of this legacy are hard to overestimate, though many do their level best to underestimate them - itself a political move on the order of other ideological erasures. Architecture poses special problems for political theory, for while it affects everyone, not everyone can affect it. Indeed, experience appears to show that it is a civic mistake to try. Witness, for example, the tangle of conflicting interests that clustered around the World Trade Center reconstruction, a series of squabbles and rejected shortlists that sadly resembled an academic committee meeting. Though it is always a collective practice - a meeting of creative mind and constructive body - 
architecture thrives on leaps of imagination, ruthless ambition, and the unlikely conjunction of money, ideas and opportunity.

As I suggested, the sustaining myth of current monumental-conceptual architecture, overturning the "organizational anonymity" of the post-war period, is the cult of the celebrity-architect, understood to be one part rogue genius and one part savvy media manipulator: Howard Roark crossed with, as it were, Madonna. This phenomenon has shown all the dismal signs of a standard mass-culture feedback loop, such that, as in all phantom economies, even stories dismissing the celebrity architects become part of the system of celebrity. Architectural discourse disappears inside successive selfreflexive spirals, obscuring the real questions of community-creation and economic impact posed by large civic buildings: How is public space affected? How is the given city as a whole benefited? How is your experience, and mine, altered by this new place, this addition to a shared horizon of concern, the cityscape? Architects tend to view their work either as a matter of material manipulation, entirely devoid of ideational responsibility, or, fleeing to the opposite pole, as a kind of art form immune from outside challenge or evaluation. Neither attitude is helpful when we want to assess architecture in its real context, as the occasion for thought, the embodiment of political consciousness, as the enabler of (or, unfortunately, barrier to) vibrant citizenship.

\section{The Space of Appearance}

Architectural beauty belongs to what Arthur Danto calls "the third realm" of beauty: the realm of application, where beauty is neither natural (sunsets and fields) nor purely artistic (the so-called fine arts). It is fair to say, given that this realm also includes 
fashion, advertising, design, cosmetics, interior decoration and much of everyday visual culture, that it is a far more significant feature of urban life than the other two combined in volume certainly but also, we might say, politically (Abuse $68 \mathrm{ff}$.). There are political issues in fine art, yes, but generally they concern the basic question of whether (sometimes, less often, how) such art should be political. In the third realm, beauty is always political because it always addresses, in some manner, how to live. Third-realm beauty may be aspirational, admonitory, or inspiring. It may, too frequently, be merely consumeristic. It may be all of these at once. But it is in this realm that urbanites actualize whatever remains of the old Platonic connection between beauty and justice, occupying their public spaces to negotiate the daily business of being citizens together, finding inspiration and provocation alike in their shared surroundings.

Architecture, more than the other aspects of the third realm, must grapple with these political implications. It is, after all, a form of aesthetic immortality, inflicting itself on future generations and shaping thought and action for decades, sometimes centuries. ${ }^{4}$ Architecture is insistent, inescapable, assertive. Few paintings, and even fewer books as time goes on, can hope to do as much. And the sad truth is that a bad or banal building can easily last as long as, sometimes far longer than, a good one. Architecture exists not in the isolated context of autonomous art, where the universe of meaning inherent in a painting, say, is contextualized only by other paintings, but in a larger and more complex context where its boundaries with the street, the cityscape, the world of social meaning are permeable and fluid. I must walk around and through the building as well as gaze at it; my physical body is always implicated in its created spaces. But also my socialized 
body, my intersubjective body, ever negotiating relations with others in their myriad postures: co-workers, visitors, consumers, lovers, citizens. The building stands firm, perhaps representing but also disclosing - creating, shaping - social relations over time.

That endurance, sometimes painful, possibly uplifting, is part of what Hannah Arendt meant when she recognized the city as a "worldly artifice" which can provide the durable site for our "comings and goings" as mortal creatures. The durable world is "a non-mortal home for mortal beings"; like great art and literature, it extends "a premonition of immortality ... something immortal achieved by mortal hands." Durability is essential to the city's ability to ground our projects, to give them life beyond an individual span. Sometimes, indeed, architecture itself becomes the trans-mortal project, as in the trans-generational construction of medieval cathedrals: here, meaning is achieved not by witnessing completion but by participation in the service of an imagined completion. Arendt called this durability "reification," using the term positively for once, as against the more common notion of reification as the distortions typical of power, the rendering of a current arrangement into "how things are," the exposure of which is the usual job of critical theory. Architecture in its civic role is reification redeemed, public space created, and so, finally, politics enabled. Just as democracy is the only reliable safeguard of architecture, architecture is the only reliable site of democracy. Or it might be. Arendt herself does not pursue this lead, and so leaves her emphasis on politics as conducted in a "space of appearances," an apparently abstracted public space which, notwithstanding the claims about civic durability, seems to have no concrete, that is to say, architectural rendering. (This despite the use of the phrase in Baird's title.) There is, she argues, a different and more important kind of immortality in the thoughts and deeds 
of mortal persons, the enacted narratives of life. This is the essence of politics: collective human action as a durable achievement, almost a form of art. But architecture remains, on this view, pre-political. It may enable thoughts and deeds but cannot create them. Public space is the central concept of Arendtian politics, but it is a space that does not advance us very far from the abstractions typical of more traditional political theory. Arendt does not, as it were, take public space seriously as a real place.

She is far from alone in this, and hence a third frustration, more personal still than the other two. Discussions of public space, when conducted by political theorists, tend to originate in ideas about the "public sphere," a notional space in which claims are made, objections raised, dialogue attempted. In one influential version of this idea, the public sphere is the place where all those affected by a decision are allowed to articulate their interests, this participation alone defining justice; the interests themselves are channelled and moulded by the constraints of reason, understood both as rationality (consistency, fairness) and reasonableness (willingness to acknowledge the interests of the other). Habermas and Rawls, the two leading political thinkers of the twentieth century's latter half, both defend versions of this public sphere, and, despite many important differences, share a Kantian debt in the idea of public reason (Rawls, Liberalism; Habermas, Communicative; see also Kingwell, Civil).

Many political theorists have largely accepted the cogency of this idea; and yet, objections are rife. Some are relatively minor and can be solved, or anyway managed, with extensions and refinements of the theory: Who speaks for those who cannot speak for themselves because of handicap or delusion? What if there is no agreement on what 
counts as reason? What if the most powerful media of information are systematically distorted, twisting the facts and arguments available to citizens? But some objections are even more searching, and throw the idea into larger doubt; Arendt's is one of these. The public sphere is, I have said, a notional space. That is not to say it is non-existent, just that it is a space of discourse rather than physical occupation. Where do we find it? Well, in courtrooms and parliaments and constitutional discussions; also, perhaps, voting booths and television talk shows and the op-ed pages of newspapers. Certainly, to nobody's clear benefit, in seminar rooms and lecture halls. But, having visited or occupied most of those spaces myself, I can tell you what you already know: the powerful ones are only rarely rational, and the rational ones still more rarely powerful. Moreover, access to many of them is limited; they are not, with the exception of the polling booth, the presumptive province of each and every citizen.

Such an awareness of democratic limits might prompt another thought about extension: the solution to the problem of the public sphere is to widen its scope, enlarge its horizon. But the thought quickly goes into a flatspin, not least because the idea of full participation is, depending on your political proclivities, either utopian or dangerous (or both). Habermas speaks, in Kantian vein, of the regulative ideal of reason, the distant star by which we steer our practical ship; but even if we accept the cogency of the ideal, its regulative power is much diminished, if not obliterated, if most citizens lack access to its implementation. In any case, the regulative ideal of reason, though we might accept its theoretical connection to justice if given world enough and time in the seminar room, remains rather thin political soup. It stirs few hearts and builds no walls. 
The public sphere, we are forced to conclude, is another disciplinary abstraction, an academic chimera, this one Cartesian-Kantian rather than Cartesian simpliciter. For notice that the "citizens" who are thought to occupy it are themselves attempted political versions of the isolated modern consciousness, and the imagined space itself is an ultimate $x-y-z$ abstraction, not even a two-dimensional drawing but an omni-dimensional one. The public sphere is a non-spatial space populated with consistent, articulate and well-intentioned persons whose particular interests are sufficiently plastic as to be funnelled through a grid of debate. In Rawls's well-known early version of the theory, in A Theory of Justice, isolating intuitions about fairness, persons were even asked to distance themselves from their own identities: choosing a basic social structure from a position of deracinated ignorance. Fair, perhaps; accurate, never. Subsequent revisions failed to solve the basic problem. Which is, in the words of one sharp critic, that in pursuing this abstract line of thought, political philosophy has "condemned itself to political nullity and intellectual senility" (Gray 13).

\section{Public Spaces?}

And so the Arendtian thought about public space arises as an apparent challenge to this abstraction, in focussing on public space, but one which does not go far enough, in allowing that "space" to remain as unreal as the public sphere of reason. Rather than reforming political debate, let us examine the real spaces where debate can happen. Architecture has endured its own share of utopian difficulties, of course, but it has the virtue - or we should perhaps say, the possible virtue, for nothing is guaranteed - of 
reality. Architectural thinking may be utopian in the pejorative sense, but architecture itself never is: for better or worse, it is right here in front of us, a persistent fusion of useful and useless that "indicates a utopian perspective"; this is "inherent in architecture," as the critic Albrecht Wellmer suggests (281). Architecture always both asserts itself and points beyond itself; it at once creates the thresholds of space and asks for their supervention. It achieves utility - sheltering, producing, enabling leisure - without ever freeing itself, or us, from aesthetic provocation. Aesthetic imagination, says Wellmer, is in architecture, "in the service of articulating, clarifying, and structuring and thereby transforming contexts of utility, with the aim of making sense of them" - as in making them both perceptible and intelligible (274).

Indeed, a given piece of architecture was often here before us and will likely be here when we are gone, so short is our individual stay. Unlike political participation, even on a positive (some would say romantic) view of able and dedicated democratic citizens, architecture is not optional. It influences us in countless ways both obvious and subtle. We cannot understand ourselves without it, for this is where we eat and sleep and work and raise our children. And we cannot understand it without confronting ourselves: not rational abstractions thinking rationally, but embodied persons. Persons, that is to say, with an upright posture that gives us left and right, in front of and behind, down and up; persons who find some rooms oppressive and others uplifting, some spaces intimidating and others cozy; persons who perspire and breathe, laugh or grow angry while waiting in traffic.

Three abstractions, three reductions, three problems; a similar origin for all three; and so, perhaps, a mutual solution, or at least valuable rapprochement. The discourses of 
consciousness, architecture and politics are almost completely unknown to one other, despite the fact that their interdependence seems obvious. The overarching paradox is that their respective shortcomings are, in part, a function of that ignorance. Realities of the built environment impinge on the reigning model of consciousness just as seldom as the thought of personal awareness is allowed into the foreground of architectural creation; and these, in turn, are but rarely taken as basic concerns of the political theorist. All three will benefit from further contact with each other, the consciousness of the philosophers at last finding itself somewhere in particular, embodied and situated; the abstracted space of architectural imagination recast, reshaped by working from the inside out rather than the outside in; the resulting conjunction revealing, finally, why architecture matters so very much to us, our consciousness as citizens.

It would be rash, not least because simply untrue, to suggest that a full solution to these concerns can ever be achieved. Forays into the spaces of inside and outside, the crossing of limits and thresholds, the bracketing of assumptions both powerful and many, are baby steps at best in a phenomenology of cities, a sort of anti-Cartesian reflection about the places and ways we live, that is always necessarily incomplete. Husserl acknowledges the need to be, as he said, an absolute beginner before the fact of experience - though he also demonstrated, in a familiar paradox, that the notion of absolutes is itself the reigning philosophical fiction to be dethroned. "No thought can lead to an absolute beginning," Theodor Adorno said of this insight. "Such absolutes are the product of abstraction" (37). Adorno's particular concern at the moment of making that point is, coincidentally, architecture. Speaking of functionalism's challenge to "spurious" 
or "degenerate" eclecticism - the challenge issued by Adolf Loos, that form should follow function merely as the technical solution to technical problems - Adorno reminds us of a deeper wisdom, which is that neither function, nor form, nor materials, nor even meaning is fundamental. Beauty is never a merely decorative super-addition to utility, though the functionalists were right to see that, in the modern division of aesthetic and technological realms, this becomes a practical danger. But in fact, to insist on that division - whether pro or con - is merely to perpetuate it. Failing to see that beauty and utility are inseparable is to commit another error of abstraction, violating the true nature of lived experience by trying to derive the whole from a part, an Ur-phenomenon which grounds the rest.

"[Great] architecture asks how a specific purpose can become space," Adorno says,

through which forms and materials; all these moments are reciprocally related to each other. Architectural fantasy would thus be the ability to articulate space through the sense of function, and let the sense of function become space; to translate purposes into formal structures (37).

Nothing is fundamentally given, guiding all the rest; building, like life more generally, is not a project of sovereignty but of mediation: of functions and purposes as well as materials and forms. Building is a project of finding our way, not solving a problem or decorating a shed. The key concept in that mediation is, notably, one that derives from the lived experience of an embodied person: Raumgefühl, or the feeling of space. "The feeling of space has grown together with the purposes and functions," Adorno adds. "Whenever in architecture this feeling of space asserts itself by surpassing mere functionality, it is at the same time immanent to the sense of function" (37). A valid 
functionalism does not reduce to mere functionality; it is not a one-sided rejection of "style" that becomes a style of its own. It is - or rather, would be - a practice of building ever mindful of the inseparability of form, function, materials, and purpose, the foursided causality of Aristotle.

Only close attention to the complexity of lived experience can redeem us from one-sidedness, abstraction, and reduction, in architecture as in politics - the lingering traces of a discredited yet still-present modernist cast of mind (and narrative). There is, however, a defensible aspect of the very same modernist vision, in a sense premodern in its conjunction of ethics, politics and craft, of citizenship, projection and construction. Here the "aesthetic radicalism and boldness" Wellmer notes in the early modernist architects, qualities we may still discern beneath the scalar excesses of some supermodern ones, can be foregrounded again. "[I]t is not only people who dream," Wellmer says; "cities and landscapes, and even materials also dream, and perhaps it is the task of architects to interpret these dreams and to translate them into built space" (287-8). Indeed, but not just perhaps; and then the rest is up to us, each and every one responsible for ourselves and the spaces we share.

\section{Notes}

1 "[T]he experience of a linear 'organic' flow of events is an illusion [albeit a necessary one] that masks the fact that it is the ending that retroactively confers the consistency of an organic whole on the preceding events," Slavoj Žižek notes. "What is masked is the radical contingency of the enchainment of narration, the fact that, at every point, things might have turned out otherwise" (69). 
${ }^{2}$ Hannah Arendt, to whom I will turn in a moment, was once the de rigueur theory touchstone and is no longer, having been shouldered aside by Deleuze and Guattari or Castells - a fate that has also befallen her work in political-theory circles.

3 "If this ethical concern is difficult to recognize," Alberto Pérez-Gómez writes rather hopefully, "it is because it is internal to the practice of architecture rather than an external adjunct to some formalistic or technical activity" (3).

${ }^{4}$ An artwork need not appeal to anyone, Adolf Loos said, but a house is responsible to each and every one of us (314 ff.).

\section{Works Cited}

Adorno, Theodor. "Functionalism Today." Oppositions 17 (Summer 1979): 31-41.

Arendt, Hannah. The Human Condition. Chicago: University of Chicago Press, 1998.

Augé, Marc. Non-places: Introduction to an Anthropology of Supermodernity. London/New York: Verso, 1995.

Baird, George. The Space of Appearance. Cambridge, Mass.: MIT Press, 1995.

Casey, Edward S. The Fate of Place: A Philosophical History. Berkeley: University of California Press, 1997.

-. Getting Back into Place: Toward a Renewed Understanding of the Place-World. Bloomington: Indiana University Press, 1993.

Danto, Arthur. The Abuse of Beauty: Aesthetics and the Concept of Art. Chicago: Open Court, 2003.

—. Beyond the Brillo Box: The Visual Arts in Post-Historical Perspective. Berkeley: University of California Press, 1992.

Deleuze, Gilles and Félix Guattari. A Thousand Plateaus: Capitalism and Schizophrenia. Trans. Brian Massumi. Minneapolis: University of Minnesota Press, 1987.

Denari, Neil. Gyroscopic Horizons. Princeton: Princeton Architectural Press, 1999.

Frampton, Kenneth. "The Status of Man and the Status of his Objects: A Reading of The Human Condition." Hannah Arendt: The Recovery of the Public World. Ed. Melvyn A. Hill. New York: St. Martin's Press, 1979. 
Gray, John. "Against the New Liberalism: Rawls, Dworkin and the Emptying of Political Life." Times Literary Supplement (3 July1992): 13.

Habermas, Jürgen. The Theory of Communicative Action. Trans. Thomas McCarthy. Boston: Beacon Press, 1984 and 1987.

—. "Modern and Postmodern Architecture." Critical Theory and Public Life. Ed. John Forester. Cambridge, Mass.: MIT Press, 1985.

Hollier, Denis. Against Architecture: The Writings of Georges Bataille. Cambridge, Mass.: MIT Press, 1989.

Ibelings, Hans. Supermodernism: Architecture in the Age of Globalization. Rotterdam: NAi Publishing, 1998.

Jacobs, Jane. The Death and Life of Great American Cities. Revised edition. New York: Random House, 2002.

Jameson, Fredric. "Preface." The Postmodern Condition: A Report on Knowledge. By Jean-François Lyotard. Tr. Geoff Bennington and Brian Massumi. Minneapolis: University of Minnesota Press, 1984.

Jencks, Charles. Heteropolis: Los Angeles, the Riots and the Strange Beauty of Hetero-architecture. London: Academy Editions, 1993.

—. The Language of Post-Modern Architecture. London: Academy Editions, 1977; fifth revised edition London: Rizzoli, 1987.

—. Daydream Houses of Los Angeles. London: Academy Editions, 1978. Kingwell, Mark. "Monumental/Conceptual Architecture." Harvard Design Magazine 19 (Fall 2003/Winter 2004). <http://www.gsd.harvard.edu/research/publications/ hdm/back/19_kingwell.html>

—. The World We Want: Virtue, Vice, and the Good Citizen. Toronto: Viking, 2000

-. A Civil Tongue: Justice, Dialogue, and the Politics of Pluralism. University Park: Pennsylvania State University Press, 1995.

Leach, Neil, ed. Rethinking Architecture: A Reader in Cultural Theory. London: Routledge, 1997.

Loos, Adolf. Samtliche Schriften. Ed. Franz Glück. Vienna/Munich: Brenner Verlag, 1962. 
Lyotard, Jean-François. La Condition postmoderne: rapport sur le savoir. Paris: Editions de Minuit, 1979; The Postmodern Condition: A Report on Knowledge. Trans. Geoff Bennington and Brian Massumi. Minneapolis: University of Minnesota Press, 1984.

Merkel, Jayne. "The Museum as Artifact." Wilson Quarterly (Winter 2002): 66-79.

Pérez-Gómez, Alberto. "Introduction." Architecture, Ethics, and Technology. Ed. Louise Pelletier. Montréal: Institut de recherche en histoire de l'architecture, 1994.

Rawls, John. Political Liberalism. New York: Columbia University Press, 1993.

—. A Theory of Justice. Cambridge, Mass.: Belknap Press, 1971.

Rybczynski, Witold. The Look of Architecture. Oxford: Oxford University Press, 2001.

Ryle, Gilbert. Dilemmas: The Tarner Lectures 1953. Cambridge: Cambridge University Press, 1969.

Sennett, Richard. The Fall of Public Man. Cambridge: Cambridge University Press, 1977.

Silver, Nathan. "Architect Talk." The State of the Language. Ed. Leonard Michaels and Christopher Ricks. Berkeley: University of California Press, 1980. 324-30.

Wellmer, Albrecht. "Architecture and Territory." Trans. David Midgley. Endgames: The Irreconcilable Nature of Modernity. Cambridge, Mass.: MIT Press, 1998.

Wittgenstein, Ludwig. Philosophical Investigations. Trans. G. E. M. Anscombe. New York: Macmillan, 1958.

Žižek, Slavoj. Looking Awry: An Introduction to Jacques Lacan through Popular Culture. Cambridge, Mass.: MIT Press, 1991. 